\title{
EDUCATIONAL OPPORTUNITY WISATAWAN DALAM MELAKUKAN PERJALANAN WISATA DAN PENGARUHNYA TERHADAP TINGKAT PENGETAHUAN DAN KEPUASAN WISATAWAN DI SUMATERA BARAT
}

\author{
Sarbaitinil $^{1}$, I Wayan Thariqy Kawakibi Pristiwasa ${ }^{2}$ \\ Akademi Pariwisata Bunda Padang, Politeknik Pariwisata Batam \\ bet_sarbaitinil@yahoo.co.id; thariqy@btp.ac.id
}

Korespondensi pada penulis :

Sarbaitinil, Telp: 08116612368

Email: bet_sarbaitinil@yahoo.co.id

\begin{abstract}
This study aims to find out how big educational tourist opportunities in travel and its influence on the level of knowledge and satisfaction of tourists in West Sumatra. This study uses quantitative descriptive research method with reference to the concept of educational opportunity and the level of satisfaction to tourists. Population in this research is social situation that is government, stakeholder, society and tourists. The instrument in this study is a questionnaire distributed to tourists visiting the province of West Sumatra through the area of cultural tourism in 2016, interview guides and observations, using Coding model, interpretation and congrulation. Research results indicate that: (1) Tourists visiting West Sumatera have the opportunity to learn the cultural uniqueness, it's just that tourists have not felt the level of satisfaction of tourism in West Sumatra. This is caused by the obstacles that exist in tourist sites for example, the ability of the community to serve tourists well, the ability of public communication is limited to tourists. Thus, the educational opportunity of tourists who travel is classified as psychological satisfaction. The satisfaction of tourists is more seen from the supporting facilities and tourist attractions (2) educational opportunity that significant tourists with the satisfaction of tourists in West Sumatra Fhit of 5.189 with a value of significance $=0.007$. The value is small from 0.05. Educational opportunity is an information for tourists in a travel tour to fit the level of customer satisfaction.
\end{abstract}

Keywords: educational opportunity; cultural uniqueness; society; amenity, tourist

\begin{abstract}
Abstrak
Penelitian ini bertujuan untuk mengetahui seberapa besar peluang wisata pendidikan dalam perjalanan dan pengaruhnya terhadap tingkat pengetahuan dan kepuasan wisatawan di Sumatera Barat. Penelitian ini menggunakan metode penelitian deskriptif kuantitatif dengan mengacu pada konsep peluang pendidikan dan tingkat kepuasan kepada wisatawan. Populasi dalam penelitian ini adalah situasi sosial yaitu pemerintah, stakeholder, masyarakat dan wisatawan. Instrumen dalam penelitian ini adalah kuesioner yang dibagikan kepada wisatawan yang berkunjung ke provinsi Sumatera Barat melalui kawasan wisata budaya pada tahun 2016, panduan wawancara dan observasi, menggunakan model Coding, interpretasi dan kongrulasi. Hasil penelitian menunjukkan bahwa: (1) Wisatawan yang berkunjung ke Sumatera Barat memiliki kesempatan untuk mempelajari keunikan budaya, hanya saja wisatawan belum merasakan tingkat kepuasan pariwisata di Sumatera Barat. Hal ini disebabkan oleh
\end{abstract}

Citation: Sarbaitinil, \& Pristiwasa, I. (2018). Educational Opportunity Wisatawan Dalam Melakukan Perjalanan Wisata dan Pengaruhnya Terhadap Tingkat Pengetahuan dan Kepuasan Wisatawan di Sumatera Barat. Jurnal Pariwisata Pesona, 3(1). doi:10.26905/jpp.v3i1.2043 
kendala yang ada di lokasi wisata misalnya, kemampuan masyarakat untuk melayani wisatawan dengan baik, kemampuan komunikasi publik terbatas pada wisatawan. Dengan demikian, peluang pendidikan wisatawan yang bepergian diklasifikasikan sebagai kepuasan psikologis. Kepuasan wisatawan lebih dilihat dari fasilitas pendukung dan tempat wisata (2) kesempatan pendidikan yang signifikan wisatawan dengan kepuasan wisatawan di Sumatera Barat Fhit sebesar 5,189 dengan nilai signifikansi = 0,007 . Nilainya kecil dari 0,05. Kesempatan pendidikan merupakan informasi bagi wisatawan dalam suatu perjalanan wisata agar sesuai dengan tingkat kepuasan pelanggan.

Kata kunci : kesempatan pendidikan; keunikan budaya; masyarakat; amenity, turis

\section{PENDAHULUAN}

Sumatera Barat saat ini menjadi salah satu daerah tujuan wisata di Indonesia. Tidak hanya wisatawan nusantara, wisatawan mancanegara jumlahnya sudah cukup tinggi warawiri di Sumatera Barat. Para wisatawan ini dipengaruhi oleh faktor pendorong dan faktor penarik. Faktor pendorongnya adalah keinginan dari wisatawan sendiri untuk melakukan perjalanan wisata. Suwantoro (2004:17) menyebutkan bahwa motivasi yang mendorong wisatawan untuk mengadakan perjalanan wisata adalah (1) dorongan kebutuhan untuk berlibur dan berekreasi, (2) dorongan kebutuhan pendidikan dan penelitian, (3) dorongan kebutuhan keagamaan, (4) dorongan kebutuhan kesehatan, (5) dorongan atas minat terhadap kebudayaan dan kesenian, (6) dorongan kepentingan keamanan, (7) dorongan kepentingan hubungan keluarga, dan (8) dorongan kepentingan politik. Sedangkan faktor penariknya adalah faktor-faktor yang berasal dari objek wisata yang dikunjungi.

Sumatera Barat memiliki bermacam-macam jenis wisata seperti wisata religi, wisata pertanian, wisata konvensi, wisata cagar alam, wisata bahari, wisata sejarah, dan wisata budaya. Wisata budaya yaitu perjalanan yang dilakukan atas dasar keinginan untuk memperluas pandangan hidup seseorang dengan jalan mengadakan kunjungan atau peninjauan ketempat lain atau ke luar negeri, mempelajari keadaan rakyat, kebiasaan adat istiadat mereka, cara hidup mereka, budaya dan seni mereka. Wisata-wisata budaya di Sumatera Barat cukup potensial menarik wisatawan. Seperti pesta Hoyak Tabuik di Pariaman, International Songket Carnival di Sawahlunto, Tradisi Baombai di Sijunjung, dan Pacu Jawi di Tanah Datar.

Ketika event budaya ini digelar, Sumatera Barat diserbu ratusan bahkan ribuan wisatawan asing setiap tahunnya. Rata-rata wisatawan asing yang datang hanya sedekar untuk melihat bagaimana perhelatan budaya itu dilaksanakan, selain itu juga wisatawan asing meninjau dan mendokumentasikan. Wisatawan asing juga menyediakan waktu 
untuk mengamati dan mempelajari setiap prosesi perhelatan budaya di Sumbar. Setelah dilakukan wawancara dengan 15 orang turis, mereka mengeluhkan masyarakat yang tinggal di sekitar wisata budaya belum mampu terlihat sebagai masyarakat sadar wisata. Kebanyakan ditemukan masyarakat cuek terhadap wisatawan asing yang datang. Masalah ini sangat dirasakan wisatawan asing yang tidak ditemani oleh guide. Sehingga, waktu yang telah disediakan tidak sepenuhnya dipergunakan untuk mempelajari atraksi-atraksi budaya yang digelar.

Wisatawan asing yang datang ke Sumbar dengan tujuan mempelajari wisata budaya hanya sebagian kecil bertambah pengetahuannya tentang atraksi budaya Sumbar yang dikunjungi. Idealnya wisatawan asing menginginkan untuk mengetahui secara keseluruhan seluk beluk atraksi wisata budaya, agar nantinya wisata budaya Sumbar dilihat tidak hanya sebagai seni tetapi terdapat hal-hal yang bisa mereka jadikan sebagai pedoman dan pandangan hidup. Jika ditanya tentang kepuasan wisatawan asing secara psikologis ketika berkunjung ke objek wisata budaya di Sumbar, ditemukan ketidakpuasan di hati mereka. Padahal kepuasan wisatawan merupakan sesuatu yang sangat penting diperhatikan dan diprioritaskan, karena menurut hasil penelitian Sutanto (2016) menyatakan bahwa kepuasan pelanggan sangat bermanfaat untuk menjaga hubungan antara perusahaan dan para pelanggan agar menjadi harmonis, serta memberikan dasar yang baik untuk pembelian ulang. Dalam hal penelitian ini pelanggan yang dimaksud adalah wisatawan dan perusahaan adalah daerah wisata dengan segala pemangku kebijakan, masyarakat dan pelaku pariwisata itu sendiri.

Ketidakpuasan merupakan respon wisatawan terhadap ketidaksesuaian/ diskormasi yang dirasakan antara harapan sebelumnya dengan hasil yang didapat. Hasil wawancara menggambarkan wisatawan asing masih ingin datang kembali tahun depan ke Sumbar untuk menggali lebih dalam lagi tentang wisata budaya Sumbar karena mereka merasa wisata budaya Sumbar sangat unik dan tidak kalah dengan wisata budaya di daerah-daerah lain di Indonesia seperti Bali.

Istilah educational jika dilihat dalam Bahasa Indonesia adalah pendidikan yang dapat diartikan pembimbingan berkelanjutan (to lead forth). Maka, dapat diartikan secara etimologis adalah mencerminkan keberadaan pendidikan yang berlangsung dari generasi ke generasi sepanjang eksistensi kehidupan manusia. Secara teoritis Djumransjah (2004:22) mengemukakan pendidikan adalah usaha manusia untuk menumbuhkembangkan potensipotensi bawaan, baik jasmani, maupun rohani sesuai dengan nilai-nilai yang ada dalam masyarakat dan kebudayaan. 
Menurut UU SISDIKNAS No. 20 tahun 2003 "pendidikan adalah usaha sadar dan terencana untuk mewujudkan suasana belajar dan proses pembelajaran agar peserta didik secara aktif mengembangkan potensi dirinya untuk memiliki kekuatan spiritual keagamaan, pengendalian diri, kepribadian, kecerdasan, akhlak mulia, serta keterampilan yang diperlukan dirinya, masyarakat, bangsa, dan negara.

Indikator Educational Menurut Hasbullah (2001:63) faktor yang mempengaruhi pendidikan adalah sebagai berikut:

1. Ideologi

Semua manusia dilahirkan ke dunia mempunyai hak yang sama khususnya hal untuk mendapatkan pendidikan dan peningkatan pengetahuan dan pendidikan.

2. Sosial ekonomi

Semakin tinggi tingkat sosial ekonomi memungkinkan seseorang mencapai tingkat pendidikan yang lebih tinggi.

3. Sosial budaya

Masih banyak orang tua yang kurang menyadari akan pentingnya pendidikan formal bagi anak-anaknya.

4. Perkembangan IPTEK

Perkembangan IPTEK menuntut untuk selalu memperbaharui pengetahuan dan keterampilan agar tidak kalah dengan negara maju.

5. Psikologi

Konseptual pendidikan merupakan alat untuk mengembangkan kepribadian individu agar lebih bernilai.

Pengertian Pengetahuan adalah hasil penginderaan manusia, atau hasil tahu seseorang terhadap obyek melalui indera yang dimilikinya (mata, hidung, telinga, dan sebagainya) (Notoatmodjo, 2005:50). Tingkat pengetahuan yang cukup didalam domain kognitif mempunyai 6 tingkatan, yaitu (Notoatmodjo, 2003) :

1. Tahu (Know)

Tahu diartikan sebagai mengingat suatu materi yang telah pelajari sebelumnya. Termasuk ke dalam pengetahuan tingkat ini adalah mengingat kembali (recall) sesuatu yang spesifik dari seluruh bahan yang dipelajari atau rangsangan yang telah diterima. Oleh sebab itu, tahu ini merupakan tingkat pengetahuan yang paling rendah. Kata kerja untuk mengukur bahwa orang tahu tentang apa yang dipelajari antara lain menyebutkan, menguraikan, mendefinisikan, menyatakan dan sebagainya. 
2. Memahami (Comprehention)

Memahami diartikan sebagai suatu kemampuan untuk menjelaskan secara benar tentang objek yang diketahui, dan dapat menginterpretasikan materi tersebut secara benar. Orang yang telah paham terhadap objek atau materi harus dapat menjelaskan, menyebutkan contoh, menyimpulkan, meramalkan, dan sebagainya terhadap objek yang dipelajari.

3. Aplikasi (Application)

Aplikasi diartikan sebagai kemampuan untuk menggunakan materi yang telah dipelajari pada situasi atau kondisi real (sebenarnya). Aplikasi disini dapat diartikan sebagai aplikasi atau penggunaan hukum-hukum, rumus, metode, prinsip dan sebagainya dalam konteks atau situasi yang lain.

4. Analisis (Analysis)

Analisis adalah kemampuan untuk menjabarkan materi atau suatu objek ke dalam komponen-komponen, tetapi masih di dalam satu struktur organisasi, dan masih ada kaitannya satu sama lain. Kemampuan analisis ini dapat dilihat dari penggunaan kata kerja, seperti dapat menggambarkan (membuat bagan), membedakan, memisahkan, mengelompokkan, dan sebagainya.

5. Sintesis (Synthesis)

Sintesis menunjuk kepada suatu kemampuan untuk meletakkan atau menghubungkan bagian-bagian di dalam suatu bentuk keseluruhan yang baru. Dengan kata lain, sintesis adalah suatu kemampuan untuk menyusun formulasi baru dari formulasi-formulasi yang ada.

6. Evaluasi (Evaluation)

Evaluasi ini berkaitan dengan kemampuan untuk melakukan justifikasi atau penilaian terhadap suatu materi atau objek. Penilaian-penilaian itu didasarkan pada suatu kreteria yang ditentukan sendiri, atau menggunakan kriteria-kriteria yang telah ada.

Pengertian kepuasan dapat dirasakan setelah wisatawan membandingkan pengalaman mereka dalam menikmati objek wisata. Kotler (2014:150) mengemukakan "kepuasan adalah perasaan senang atau kecewa yang muncul setelah membandingkan kinerja (hasil) produk yang dipikirkan terhadap kinerja (atau hasil) yang diharapkan." Dari definisi tersebut dapat dikatakan apabila kinerja produk tidak sesuai dengan harapan wisatawan dan bila harapan terlalu rendah, maka wisatawan tidak akan puas dan berujung kecewa. Jika kinerja sesuai dengan harapan-harapan maka wisatawan akan merasa puas, 
dan apabila kinerja melampaui harapan, maka wisatawan akan merasa gembira atau sangat puas.

Selanjutnya, Richard Oliver (Barnes, 2003:64) mendefinisikan "kepuasan adalah tanggapan pelanggan atau terpenuhinya kebutuhannya. Hal itu berarti penilaian bahwa suatu bentuk dari satuan barang atau jasa itu sendiri, memberikan tingkat kenyamanan yang terkait dengan pemenuhan kebutuhan di bawah harapan atau pemenuhan kebutuhan melebihi harapan pelanggan."

Berdasarkan uraian definisi di atas, menunjukkan bahwa kepuasan merupakan suatu pemenuhan harapan. Pelanggan dapat dikatakan puas dengan produk maupun pelayanan yang diberikan apabila harapan pelanggan telah sesuai bahkan melebihi harapan. Pengukuran kepuasan wisatawan perlu mengukur kepuasan guna melihat umpan balik maupun masukan yang dapat diambil oleh perusahaan untuk keperluan pengembangan dan implementasi strategi peningkatan kepuasan pelanggan Koteler (1999:54) mengemukakan bahwa terdapat empat metoda untuk mengukur kepuasan yaitu:

1. Sistem keluhan dan saran. Setiap perusahaan yang berpusat pada pelanggan perlu memberikan kesempatan bagi pelanggannya untuk menyampaikan saran, pendapat dan keluhan mereka.

2. Survei kepuasan pelanggan. Perusahaan tidak dapat beranggapan bahwa sistem keluhan dan saran dapat menggambarkan secara lengkap kepuasan dan kekecewaan pelanggan. Perusahaan yang responsif mengukur kepuasan pelanggan dengan mengadakan survey berkala. Mereka mengirimkan daftar pertanyaan atau menelepon suatu kelompok acak dari pembeli mereka untuk mengetahui perasaan mereka terhadap berbagai aspek kinerja perusahaan.

3. Ghost shopping. Metode ini dilakukan dengan cara memperkerjakan beberapa orang untuk berperan sebagai pembeli potensial produk perusahaan pesaing untuk melaporkan titik-titik kuat manapun titik titik lemah mereka alami waktu membeli produk perusahaan maupun produk pesaing.

4. Lost customer analysis (analisis pelanggan yang beralih). Perusahaan sebaiknya menghubungi para pelanggan yang telah berhenti membeli atau yang telah berpindah pemasok agar dapat memahami mengapa hal ini terjadi dan supaya dapat mengambil kebijaksanaan perbaikan atau penyempurnaan selanjutnya.

Educational Opportunity wisatawan dalam melakukan perjalanan wisata dan pengaruhnya terhadap tingkat pengetahuan dan kepuasan wisatawan di Sumatera Barat 
dapat dilihat dari faktor aksesbilitas, atraksi dan amenitas dimana aksesbilitas dalam sektor pariwisata berkenaan dengan tingkat kemudahan seorang wisatawan mencapai objek wisata baik secara jarak geografis atau kecepatan teknis, serta tersedianya sarana transportasi ke tempat tujuan tersebut.

Faktor pendukung lainnya adalah atraksi wisata yang dapat diartikan segala sesuatu yang terdapat di daerah wisata meliputi benda-benda hasil ciptaan manusia dan tata cara hidup masyarakat yang dapat dibedakan menjadi :

1. Site attraction (tempat yang menarik, tempat dengan iklim yang nyaman, pemandangan yang indah dan tempat bersejarah).

2. Event attraction (tempat yang berkaitan dengan pariwisata, misalnya konfrensi, pameran olah raga, festival budaya dan lain-lain ).

Adapun jenis-jenis dari atraksi wisata diantaranya adalah benda-benda yang tersedia dan terdapat di alam semesta yang dalam istilah pariwisata di sebut dengan Natural amenities yang termasuk dalam kelompok ini adalah:

1. Iklim, misalnya cuaca cerah (clean air), banyak cahaya matahari (sunny day), sejuk (mild), kering (dry), panas (hot), hujan (wet) dan sebagainya.

2. Bentuk tanah dan pemandangan (land configuration and landscape)

3. Hutan belukar (the sylvan elemen)

4. Flora dan fauna (uncommon vegetation, birds, fish, wild life, national park, hunting and photographic)

5. Pusat kesehatan (Health center) seperti sumber air mineral (Natural spring of mineral water), mandi lumpur (mud baths), sumber air panas (hot springs).

6. Hasil ciptaan manusia (Man made supply) terdiri dari empat bagian penting yaitu bendabenda sejarah kebudayaan dan keagamaan (Historical, cultural and religious)

7. Tata cara hidup masyarakat (the way life) terdiri dari adat istiadat, bagaimana kebiasaan hidupnya.

Kebutuhan wisatawan tidak hanya menikmati aksesbilitas dan atraksi wisata saja akan tetapi juga harus ditunjang dengan amenitas yang dapat diartikan sebagai suatu sarana dan prasarana yang harus disediakan oleh pengelola untuk kebutuhan wisatawan, contoh sarana dan prasarana wisata dapat berupa seperti akomodasi, sarana kebersihan, kesehatan, keamanan, komunikasi, restaurant, transportasi dan lain-lain. 
Penelitian terdahulu yang menjadi acuan penulis dalam melakukan penelitian, sehingga dalam melakukan penelitian dapat memperkaya teori yang digunakan dalam mengkaji penelitian yang dilakukan. Dari penelitian terdahulu, tidak ditemukan penelitian dengan judul yang sama dengan penelitian ini. Namun, penulis mengangkat beberapa penelitian sebagai referensi dalam memperkaya bahan kajian pada penelitian ini. Berikut merupakan beberapa penelitian terdahulu berupa jurnal yang relevan:

Tabel 1.1 Penelitian Terdahulu

\begin{tabular}{|c|c|c|c|}
\hline $\begin{array}{l}\text { Nama } \\
\text { Peneliti }\end{array}$ & Judul Penelitian & Hasil Penelitian & Perbedaan Penelitian \\
\hline $\begin{array}{l}\text { Aprinal } \\
\text { eko } \\
\text { saputra } \\
2017\end{array}$ & $\begin{array}{l}\text { Pengaruh media sosial } \\
\text { instagram terhadap } \\
\text { kunjungan wisatawan ke } \\
\text { pulau Sirandah Padang }\end{array}$ & $\begin{array}{l}\text { Menunjukkan bahwa media } \\
\text { sosial instagram berpengaruh } \\
\text { secara positif terhadap motivasi } \\
\text { kunjungan wisatawan besarnya } \\
\text { pengaruh tersebut adalah } 35 \% \\
\text { sedangkan } 65 \% \text { lainnya di } \\
\text { pengaruhi oleh variable di luar } \\
\text { penelitian }\end{array}$ & $\begin{array}{l}\text { Mengidentifikasi potensi yang } \\
\text { ada di objek penelitian yang } \\
\text { berpedoman terhadap tingkat } \\
\text { kepuasan wisatawan } \\
\text { berdasarkan educational } \\
\text { opportunity }\end{array}$ \\
\hline $\begin{array}{l}\text { Duky } \\
\text { ardhana, } \\
2014\end{array}$ & $\begin{array}{l}\text { Pengaruh kualitas objek } \\
\text { wisata Sumatera Barat } \\
\text { terhadap kepuasan } \\
\text { wisatawan }\end{array}$ & $\begin{array}{l}\text { Menunjukan bahwa wisatawan } \\
\text { memiliki rasa aman,nyaman dan } \\
\text { mendapatkan kualitas penyajian } \\
\text { informasi wisata serta } \\
\text { kelengkapan fasilitas objek } \\
\text { wisata }\end{array}$ & $\begin{array}{l}\text { Mengidentifikasi objek yang } \\
\text { ada di objek penelitian serta } \\
\text { metode yang digunakan }\end{array}$ \\
\hline $\begin{array}{l}\text { Gusneli, } \\
2016\end{array}$ & $\begin{array}{l}\text { Pengaruh fasilitas } \\
\text { pariwisata terhadap } \\
\text { kepuasan pengunjung ke } \\
\text { objek wisata air terjun } \\
\text { Baying Sani kabupaten } \\
\text { Pesisir Selatan provinsi } \\
\text { Sumatera Barat }\end{array}$ & $\begin{array}{l}\text { Menunjukan bahwa fasilitas } \\
\text { wisata dan tingkat kepuasan } \\
\text { pengunjung di air terjun Baying } \\
\text { Sani bagus sebesar } \quad(53,60 \%)\end{array}$ & $\begin{array}{l}\text { Mengidentifikasi objek } \\
\text { penelitian dan educational } \\
\text { opputunity dan tingkat } \\
\text { kepuasan wisatawan yang } \\
\text { melakukan perjalanan wisata } \\
\text { kepuasan secara psikologis } \\
\text { dilihat fasilitas pendukung dan } \\
\text { atraksinya }\end{array}$ \\
\hline
\end{tabular}

Sumber : Hasil Penelitian 2016

\section{METODOLOGI PENELITIAN}

Desain yang digunakan dalam penelitian ini adalah deskriptif kuantitatif. Populasinya adalah wisatawan yang berkunjung ke Sumatera Barat melalui Bandara Internasional Minangkabau tahun 2016 dengan jumlah sampel 81 responden.

Dalam pengumpulan data yang diperlukan sebagai landasan penyusunan penelitian ini, maka penulis melakukan penelitian lapangan dengan menggunakan metode:

1. Teknik Observasi, yaitu data yang didapatkan melalui pengamatan langsung pada objek penelitian untuk mendapatkan informasi tentang educational opportunity 
wisatawan dalam melakukan perjalanan wisata dan pengaruhnya terhadap tingkat kepuasan wisatawan yang datang berkunjung ke kota Padang melalui Bandara BIM. Observasi ini dilaksanakan di beberapa tempat dan kawasan wisata di Sumatera Barat.

2. Teknik Wawancara, yaitu melakukan wawancara langsung dengan pihak yang berkompeten tentang permasalahan yang diangkat dan diharapkan dapat memperoleh informasi yang akurat sehubungan dengan educational opportunity wisatawan yang berkunjung ke beberapa kawasan wisata yang ada di Sumatera Barat. Wawancara dilakukan dengan beberapa orang pengelola dan karyawan-karyawan beberapa kawasan wisata di Sumatera Barat, dan juga dengan wisatawan itu sendiri.

3. Kuisioner, yaitu merupakan suatu metode untuk memperoleh data yang dilakukan dengan cara memberikan daftar pertanyaan yang akan diisi oleh Responden, yakni wisatawan yang berkunjung ke beberapa kawasan wisata di Sumatera Barat.

Selanjutnya, data kuantitatif yang diperoleh melalui pemberian kuisioner di atas diolah dengan menggunakan teknik analisis data kuantitatif untuk melihat Tingkat Capaian Responden (TCR). Adapun langkah-langkahnya adalah sebagai berikut:

1. Melakukan tabulasi data terhadap angket yang telah diisi oleh responden.

2. Melakukan perhitungan setiap skor indikator.

3. Menghitung skor total.

4. Menganalisis dengan analisis persentase.

Menurut Riduwan (2009:102) untuk mengetahui tingkat pencapaian responden digunakan rumus:

$$
\text { Tingkat Pencapaian } \frac{\text { Skor rata-rata }}{\text { Skor ideal }} \times 100 \%
$$

Sedangkan untuk pengkategorian nilai pencapaian responden digunakan klasifikasi sebagai berikut:

Tabel 1.2. Kategori Pencapaian Responden

\begin{tabular}{ll}
\hline Rentang & Keterangan \\
\hline $90 \%-100 \%$ & Sangat baik \\
\hline $80 \%-89 \%$ & Baik \\
\hline $70 \%-79 \%$ & Cukup \\
\hline $60 \%-69 \%$ & Kurang \\
\hline $0 \%-59 \%$ & Sangat kurang \\
\hline
\end{tabular}


Setelah Tingkat Capaian Respondennya diperoleh, maka langkah selanjutnya adalah dilakukan Uji Persyaratan Analisis dengan menggunakan tiga bentuk, yaitu:

1. Uji Normalitas

Uji normalitas digunakan untuk mengetahui apakah data berdistribusi secara normal atau tidak. Pengujian normalitas dianalisa dengan menggunakan uji One Sample Kolmogoroy Smirnow. Kriteria pengujian adalah jika nilai signifikansi (Sig) atau nilai probabilitas $(\mathrm{p})>0,05$, maka data tersebut berdistribusi normal.

2. Uji Homogenitas

Pengujian ini dilakukan untuk melihat apakah sampel yang berasal dari populasi memiliki karakteristik yang sama atau tidak, untuk pengujian ini digunakan uji tes regresi linier. Kriteria pengujian adalah jika nilai $\mathrm{f}$ hitung lebih besar dari Ftabel maka dapat dikatakan data tersebut berasal dari populasi yang mempunyai varian yang sama atau data yang bersifat homogen.

3. Pengujian Hipotesis

Pengujian hipotesisi digunakan untuk mengetahui derajat hubungan variabel bebas dengan variabel terikat. Uji hipotesis yang digunakan adalah uji regresi sederhana. Regresi sederhana didasarkan pada hubungan fungsional ataupun antara satu variabel independen dengan satu variabel dependen. Persamaan umum regresi linier sederhana adalah:

$$
Y=a+b X
$$

Dimana :

$\mathrm{Y}=$ subyek dalam variabel dependen yang diprediksikan

$\mathrm{a}=$ harga $\mathrm{Y}$ bila $\mathrm{X}=0$ (harga konstan)

$\mathrm{b}=$ angka arah atau koefisien regresi, yang menunjukkan angka peningkatan ataupun penurunan variabel yang didasarkan pada variabel independen

$\mathrm{X}$ = subyek pada variabel independen yang mempunyai nilai tertentu

4. Uji regresi linier berganda

Analisis regresi linier berganda digunakan untuk mengukur pengaruh antara satu atau lebih variabel prediktor terhadap variabel terikat. Uji regresi linier dirumuskan sebagai berikut:

$$
Y=a+b_{1} x_{1}+b_{2} x_{2}+\ldots . .+b_{n} x_{n}
$$

Keterangan:

$\mathrm{Y}=$ variabel terikat 

a $=$ konstantsa
$b_{1} b_{2}=$ koefisien regresi
$\mathrm{x}_{1} \mathrm{x}_{2}=$ variabel bebas

Data dalam penelitian ini ada dua, yaitu data primer dan data sekunder. Dalam rangka pengumpulan data sekunder, maka peneliti menggunakan wawancara. Sedangkan dalam rangka pengumpulan data primer, peneliti melakukan observasi langsung dan juga melakukan studi dokumentasi selama beberapa hari di lapangan. Dalam proses ini, peneliti juga melakukan wawancara tidak terstruktur terhadap warga sekitar kawasan wisata. Pengolahan data dilakukan setelah data terkumpul. Dalam proses pengolahan data ini dilakukan proses pemilahan dan pengelompokan terhadap data yang diperoleh langsung di lapangan serta data sekunder. Hasil dari pengklasifikasian tersebut kemudian dibuatkan ke dalam narasi data untuk kemudian ditarik menjadi kesimpulan. Kesimpulan ini diharapkan akan mewakili perspektif masyarakat, organisasi kelembagaan, wisatawan, dan keseluruhan stakeholder yang terpaut di kawasan tersebut.

\section{HASIL DAN PEMBAHASAN}

Dalam mengkaji educational opportunity wisatawan dalam melakukan perjalanan wisata dan pengaruhnya terhadap tingkat pengetahuan dan kepuasan wisatawan di Sumatera Barat perlu dibedakan antara elemen fisik dan non fisik. Elemen fisik yang ada dapat dikuantifikasi seperti amenitas di kawasan wisata. Adapun elemen non fisik meliputi elemen yang tidak dapat dihitung, pada umumnya berkaitan dengan sosial budaya masyarakat setempat, yaitu cara hidup dan tata nilai serta perilaku. Berikut ini adalah hasil analisis tersebut:

Tabel 1.3 Variabel Educational Opportunity Wisatawan Dalam Melakukan Perjalanan Wisata Dan Pengaruhnya Terhadap Tingkat Pengetahuan Dan Kepuasan Wisatawan Di Sumatera Barat

\begin{tabular}{|c|c|c|}
\hline No Pernyataan & TCR (\%) & Kategori \\
\hline Item 1 & 80,15 & Baik \\
\hline Item 2 & 77,38 & Cukup \\
\hline Item 3 & 76,76 & Cukup \\
\hline Item 4 & 76,4 & Cukup \\
\hline Rata -rata & 77,69 & Cukup \\
\hline
\end{tabular}


Berdasarkan hasil tanggapan responden pada kuesioner yang disebarkan diperoleh tingkat capaian responden rata-rata 77,69\% dengan kategori cukup. Artinya, wisatawan merasa mendapat kesempatan untuk mempelajari keunikan budaya, serta alam Sumbar dan wisatawan merasakan perjalanan wisata selama di Sumbar cukup menambah pengalaman mereka. Hanya saja yang harus diperbaiki adalah keramahan masyarakat terhadap wisatawan yang datang ke Sumbar. Seiring perkembangan pariwisata Sumbar hendaknya dibekali dengan pengetahuan-pengetahuan bagaimana memperlakukan wisatawan agar wisatawan mendapatkan pengalaman baru di Sumbar.

Tabel 1.4 Variabel Tingkat Pengetahuan

\begin{tabular}{|c|c|c|}
\hline No Pernyataan & $\begin{array}{l}\text { TCR } \\
(\%)\end{array}$ & Kategori \\
\hline Item 1 & 77,23 & Cukup \\
\hline Item 2 & 77,69 & Cukup \\
\hline Item 3 & 78 & Cukup \\
\hline Item 4 & 77,38 & Cukup \\
\hline Rata -rata & 77,57 & Cukup \\
\hline
\end{tabular}

Rata -rata tingkat capaian responden di atas menunjukkan tingkat pengetahuan wisatawan berkategori cukup dengan nilai 77,57\%. Hal ini menunjukkan pengalaman selama melakukan perjalanan wisata sambil mempelajari budaya, keunikan daerah serta keindahan alam cukup memberikan pengetahuan kepada wisatawan. Hanya saja wisatawan belum merasakan tingkat kepuasan terhadap galian mereka pada pariwisata yang ada di Sumbar. Hal ini disebabkan oleh hambatan-hambatan yang terdapat di lokasi wisata, misalnya kemampuan masyarakat melayani wisatawan dengan baik dan kemampuan komunikasi masyarakat yang terbatas dengan wisatawan asing mengakibatkan tidak semua sejarah budaya wisata Sumbar mereka ketahui. Seharusnya masyarakat berpandai-pandai ketika melayani wisatawan asing maupun mancanegara karena nanti dapat menjadi income di daerah Sumbar.

Tabel 1.5 Variabel Tingkat Kepuasan

\begin{tabular}{|c|c|c|}
\hline No Pernyataan & TCR (\%) & Kategori \\
\hline Item 1 & 78,46 & Cukup \\
\hline Item 2 & 78 & Cukup \\
\hline Item 3 & 77,38 & Cukup \\
\hline Item 4 & 81,23 & baik \\
\hline Item 5 & 85,38 & Baik \\
\hline Rata -rata & 80,09 & Baik \\
\hline
\end{tabular}


Kepuasan wisatawan merupakan ungkapan perasaaan wisatawan setelah melakukan perjalanan wisata dan menggunakan fasilitas-fasilitas pendukung objek wisata. Hasil penelitian menunjukkan tingkat capaian responden 80,09\% dengan kategori baik. Artinya, wisatawan yang melakukan perjalan ke Sumbar terlihat menikmati semua objek wisata yang tersedia di alam Sumbar. Saat ini perkembangan pariwisata Sumbar sedang gencar dibenahi oleh pemerintah setempat. Berdasarkan hasil pengamatan kepuasan dominan wisatawan terlihat ketika wisatawan melihat keindahan alam Sumbar begitu juga dengan atraksi-atraksi wisatanya. Walaupun sedang dalam proses peningkatan fasilitas, kepuasan wisatawan telah terjawab dengan keindahan-keindahan objek wisata. Apalagi jika ditambah dengan elemen-elemen pendukung kepariwisataan seperti sarana dan prasarana yang lengkap. Maka harapan mendapat tingkat kepuasan lebih tinggi bagi wisatawan tidak akan diragukan lagi.

Tabel 1.6 Hasil Uji Analisis Normalitas

One-Sample Kolmogorov-Smirnov Test

\begin{tabular}{|c|c|c|c|c|}
\hline & & $\begin{array}{l}\text { Educational } \\
\text { Opportunity }\end{array}$ & $\begin{array}{c}\text { Tingkat } \\
\text { Pengetahua } \\
n\end{array}$ & Kepuasan \\
\hline \multicolumn{2}{|l|}{$\mathrm{N}$} & 130 & 130 & 130 \\
\hline \multirow[t]{2}{*}{ Normal Parameters ${ }^{a}$} & Mean & 16.3077 & 15.5154 & 20.0231 \\
\hline & $\begin{array}{l}\text { Std. } \\
\text { Deviation }\end{array}$ & 1.82084 & 1.98144 & 2.28397 \\
\hline \multirow{3}{*}{$\begin{array}{l}\text { Most Extreme } \\
\text { Differences }\end{array}$} & Absolute & .110 & .126 & .104 \\
\hline & Positive & .106 & .126 & .104 \\
\hline & Negative & -.110 & -.104 & -.104 \\
\hline \multicolumn{2}{|c|}{ Kolmogorov-Smirnov Z } & 1.336 & 1.250 & 1.191 \\
\hline \multicolumn{2}{|l|}{ Asymp. Sig. (2-tailed) } & .056 & .088 & .117 \\
\hline
\end{tabular}

Tabel 1.6 menunjukkan bahwa nilai Asymp Sig untuk variabel keputusan pembelian adalah 0,117, produk hotel 0,088 dan harga kamar 0,056. Dengan nilai > dari 0,05, maka dapat dikatakan bahwa ketiga data terdistribusi normal. 


\section{Tabel 1.7 Hasil Uji Annova}

\begin{tabular}{|c|c|c|c|c|c|c|}
\hline \multicolumn{7}{|c|}{ ANOVA $^{b}$} \\
\hline \multicolumn{2}{|c|}{ Model } & $\begin{array}{l}\text { Sum of } \\
\text { Squares }\end{array}$ & $\mathrm{df}$ & $\begin{array}{c}\text { Mean } \\
\text { Square }\end{array}$ & $\mathrm{F}$ & Sig. \\
\hline \multirow[t]{3}{*}{1} & Regression & 50.838 & 2 & 25.419 & 5.189 & $.007 \mathrm{a}$ \\
\hline & Residual & 622.093 & 127 & 4.898 & & \\
\hline & Total & 672.931 & 129 & & & \\
\hline
\end{tabular}

Hasil uji $\mathrm{F}$ pada Tabel 1.7 di atas menunjukkan $F_{\text {hitung sebesar 5,189 dengan nilai }}$ signifikansi $=0.007$. Nilai tersebut kecil dari 0,05 dapat diartikan terdapat pengaruh signifikan antara variabel independen dengan variabel dependen yaitu educational opportunity serta tingkat pengetahuan dan kepuasan wisatawan.

\section{KESIMPULAN}

Berdasarkan hasil temuan dan analisis secara keseluruhan dapat disimpulkan dua hal. Kesimpulan yang pertama bahwa educational opportunity wisatawan dalam melakukan perjalanan wisata dan pengaruhnya terhadap tingkat pengetahuan dan kepuasan wisatawan, mendapatkan kesempatan untuk mempelajari keunikan budaya. Sedangkan kesimpulan yang kedua adalah educational opportunity wisatawan yang signifikan dengan kepuasan wisatawan di Sumatera Barat. Educational opportunity merupakan informasi bagi wisatawan dalam melakukan perjalanan wisata agar sesuai dengan tingkat kepuasan wisatawan.

Sebagai kawasan tujuan pariwisata nasional yang berada langsung di provinsi Sumatera Barat, semestinya menjadi kawasan yang diunggulkan oleh masyarakat. Dengan demikian kedepannya akan datang keuntungan baik secara finansial maupun melalui hal lain yang bisa meningkatkan kesejahteraan. Dalam hal ini perlu dilaksanakan berbagai hal, yaitu: Pertama, sosialisasi dan usaha yang gencar oleh para pemangku kepentingan serta membangun koneksi yang terpadu antara satu dan lainnya dengan baik. Kedua, perlu adanya koordinasi antara lembaga kepariwisataan daerah, perlu adanya peningkatan kualitas sumbaer daya manusia dan sumber daya alam. Ketiga, perlu adanya sebuah perencanaan konsep terhadap pariwisata dengan melibatkan lintas sektoral terkait dengan peningkatan kapasitas sumber daya bisa dilakukan melalui kegiatan pelatihan bagi kelompok sadar wisata terkait pariwisata maupun masyarakat secara langsung. Keempat, perlu adanya pelatihan pelatihan pemandu (guide) bagi para remaja dan pemuda yang ada. 
Selain memberikan mereka pendapatan hal ini juga bisa membantu peningkatan kualitas destinasi. Selain itu sumber daya lainnya juga perlu diperbaiki seperti peningkatan atraksi bagi wisatawan dan juga pembuatan saran informasi lainnya bisa juga meningkatkan kualitas dari kawasan destinasi wisata.

Selanjutnya dalam rangka meningkatkan koordinasi antara lembaga kepariwisataan yang ada di kawasan ini bisa dilakukan dengan pelaksanaan berbagai aktivitas seperti melalui pembentukan focus group discussion, mendukung peran serta asosiasi pariwisata seperti Assosiasi Travel Agent (ATA), Persatuan Hotel dan Restauran Indonesia (PHRI), Badan Promosi Pariwisata dan Himpunan Pramuwisata Indonesia, Lembaga adat untuk kawasan tersebut. Dengan adanya koordinasi antar lembaga yang baik bisa saja kedepannya dibuatkan satu paket perjalanan yang saling mendukung. Selain itu, dukungan tersebut bisa saja didorong dalam bentuk promosi kawasan bersama dengan destinasi lainnya di lingkungan Provinsi Sumatera Barat. Hal-hal tersebut apabila dilakukan ke depannya akan menjadi penting dalam rangka membantu sinergisitas antara stakeholder untuk meningkatkan peranan antara stakeholder.

Selain itu konsep educational opportunity terhadap wisatawan tersebut dapat didorong melalui intensifikasi dan penekanan atas keterlibatan serta peran dari berbagai institusi yang ada di dalam lingkungan destinasi, seperti sekolah atau perguruan tinggi yang bercirikan kepariwisataan dan, perusahaan swasta dalam bentuk corporate social responsibility secara langsung bagi masyarakat dan juga melalui penyerapan atau pelatihan tenaga kerja putera daerah yang memiliki keahlian atau minat untuk bekerja dibidang pariwisata. Dua hal-hal ini akan menjadi peningkatan yang lebih berkualitas dalam memberikan pengetahuan dan tingkat kepuasan bagi wisatawan di provinsi Sumatera Barat.

\section{DAFTAR RUJUKAN}

Ardhana, Ducky ( 2014 ). Pengaruh Kualitas Objek Wisata Sumatera Barat Terhadap Kepuasan Wisatawan : Jurnal Manajemen FE Unand Padang

A.J. Mulyadi ( 2009 ). Kepariwisataan dan Perjalanan .Jakarta: PT.Raja Grafindo Persada

Butler, R. \& Hinch, T. ( 2007 ). Tourism and Indigenous People: Issues and Implication. Amsterdam: Butterworth Heinemann.

Cascante, D.M, Brennan, M.A, \& Luloff, A.E. ( 2010 ). Community Agency and Sustainable Tourism Development: The Case La Fortuna of Costarica, Journal Sustainable Tourism, 18 (6), 735- 756. 
Damardjati, R. S. ( 2002 ). Istilah-Istilah Dunia Pariwisata. Jakarta: Pradnya Paramita

Dinas Pariwisata dan Kebudayaan. ( 2016 ). Data Potensi, Kebijakan dan daya Tarik Bidang Destinasi Pariwisata Provinsi Sumatera Barat.

Dodds, R. \& Butler, R. ( 2010 ). Barries To Implementing Sustainable Tourism Policy in Mass Tourism Destination. Tourimos: An International Multidisplinary Journal of Tourism 5(1), Spring 2010. Pp, 35-53

Eko Saputra, Aprinal ( 2017 ). Pengaruh Media Sosial Instagram Terhadap Kunjungan Wisatawan Ke Pulau Sirandah Padang; Jurnal Jurusan Administrasi Niaga Prodi Usaha Perjalanan Wisata Politeknik Negeri Padang.

Gloria, Siti ( 2016 ). Tesis Manajemen Komunikasi Tourist Information Center (TIC) Pada Dinas Kebudayaan dan Pariwisata Kota Padang.Universitas Andalas Padang.

Gusneli, ( 2016 ). Pengaruh Fasilitas Pariwisata Terhadap Kepuasan Pengunjung Ke Objek Wisata Air Terjun Baying Sani Kabupaten Pesisir Selatan Propinsi Sumatera Barat; Jurnal Fakultas pariwisata dan perhotelan UNP.

Soegiyono. (2009). Metode Penelitian Kuantitatif, Kualitatif dan Research \& Development. Bandung: Alfabeta

Sutanto. (2016). Pengaruh Sanitasi Hygiene di Area Restoran \& Main Kitchen Terhadap Kepuasan Tamu di Harris Hotel $\mathcal{E}$ Conventions Malang. Jurnal Pesona Pariwisata, Vo 2 No 1 Desember (2016) 39-46 Program Diploma III-IV Kepariwisataan Universitas Merdeka Malang. 